\title{
無線遠隔操作型移動ロボットの遭難を防ぐための 電界強度シミュレーション
}

Electromagnetic simulation to prevent disconnection of wireless communication for tele-operated mobile robot

\section{○松田崇史 渡邊浩也 羽田靖史（工学院大学）}

Takashi Matsuda, Hiroya Watanabe and Yasushi Hada, Kogakuin University

\begin{abstract}
When the tele-operated mobile robot went over its communication range accidentally, the operation would be suspended. We named this kind of trouble "the distress of mobile robot". In order to prevent the distress of mobile robot, it is necessary to estimate communications conditions around the robot by means of radio wave propagation simulation. The simulation consists of a combination of environmental shape measurement and radio propagation simulation using the shape. In this paper, we describe the trial simulation using simple ray-tracing method.
\end{abstract}

Key Words: tele-operated moble robot, wireless communication, network

\section{1. 緒言}

東日本大震災以降，災害対応ロボットの実用化が改めてク ローズアップされている．［1］実用上の大きな技術課題の一 つに，無線通信状況の推定，及び可視化がある．遠隔操作口 ボットの制御は，ロボットに搭載されたカメラ等のセンサ情 報を元に操作者が行動指示を送る, 通信を介した広義のフィ 一ドバック系を構成する。 そのため, 通信が切れればロボッ 卜は停止し，それ以降の運用が不可能となる。ここではこれ を「ロボットの遭難」と呼ぶ.（図 1 ) 特に危険な被災地にお いて人間の代替として運用される災害対応ロボットでは，遭 難したロボットを回収することは本末転倒であるため, その まま放置されることとなる。実際に，東京電力福島第一原子 力発電所で用いられていた「クインス改」 [2]「Survey Runner」 [3]などはケーブル切断による通信途絶により遭難し, 現在も

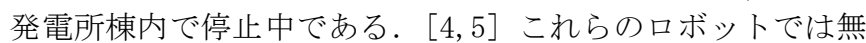
線通信の不確実性を嫌い有線方式での通信を行っていたが， 無線通信の信頼性がより向上すれば，重い通信ケーブルを用 いる有線方式よりも利点が多いことは自明である。

また，信頼性がない無線通信を用いた運用では，操作者（消 防隊員）は遭難を恐れて，本来運用可能であるはずの範囲ま でロボットを進めず，自らロボットの運用範囲を狭めてしま う。この原因は通信可能範囲を操作者がわからないからであ り, 状態の可視化が必要不可欠である。

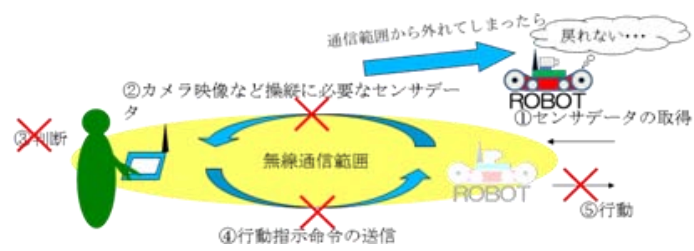

Fig.1 ロボットの遭難

\section{2. 本研究の目的}

本研究では，ロボットの遭難を防止するために，未知屋内 環境における将来の電波状況をシミュレーションにより推定 し操縦者に提示するシステムの開発を目的とする。これには 未知環境の形状データ生成と電波伝搬のシミュレーションが 必要であるが，本稿では電波伝搬のシミュレーションについ て述べる。

\section{1 自由伝搬}

\section{3. 電波伝搬の性質}

一般に，アンテナから放出された電波は広がりを持ち，各 地点に伝搬した電力は電界強度として表される。真空中の電 界強度は(1)式で減衰する。このような送受信機間に特別な障 害がない電波は直接波と呼ばれ，直接波の減衰は自由伝搬損 失と呼ばれる。なお，電界強度の単位は電力 $1 \mathrm{~mW}=0 \mathrm{dBm}$ を 基準としており，アンテナ利得は理想的な無指向性（アイソ トロピック) アンテナの利得を $0 \mathrm{dBi}$ とした単位である.

$$
\mathbb{L}=-20 \log \left(\frac{4 \pi d}{\lambda}\right)+10 \log (\mathrm{P})+\mathrm{Gt}+\mathrm{Gr}
$$

$$
\begin{aligned}
& \mathrm{L}: \text { 電界強度 }[\mathrm{dBm}] \\
& \mathrm{d}: \text { 送信アンテナからの距離 }[\mathrm{m}] \\
& \lambda: \text { : 波長 }[\mathrm{m}] \\
& \mathrm{P}: \text { 発信機の電力 }[\mathrm{mW}] \\
& \mathrm{Gt}: \text { 送信アンテナ利得: }[\mathrm{dBi}] \\
& \mathrm{Gr}: \text { 受信アンテナ利得:[dBi] }
\end{aligned}
$$

また電波は，衝突などの伝搬媒質の変化により，反射，回 折，透過、散乱などの諸性質を持つ. 実際に受信機で受信さ れる電界強度は，直接波のみならず，環境中で複雑な反射， 回折，透過、散乱等を行って届いた複数の電界強度の和で表 される。

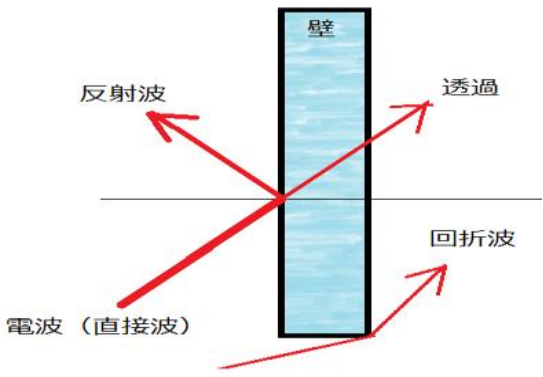

Fig.2 電波の諸性質 


\section{3 電波伝搬シミュレーション法}

送信された電波の振る舞いを計算し, 各地点での電界強度 をコンピュータ上で求めることを電波伝搬シミュレーション と呼ぶ.シミュレーション法にはレイトレース法, 有限要素 法 [6]，時間領域差分法 [7]，などが存在する.レイトレース 法は電波を光束として模擬する方法であり，あまり正確では ないが高速に計算出来るものの, 環境の複雑さに応じて計算 量が増大寸る。このような性質から，レイトレース法は放送 波や携帯電話電波の受信可能エリアの簡易推定によく用いら れる。一方，有限要素法や時間領域差分法ではより正確かつ 細やかなシミュレーションが可能である. 環境の複雑さは計 算量に影響しないが，環境の広さや電波の波長に応じて計算 量が膨大となるため，電子機器内部の電磁環境適合性 (EMC) 調査やアンテナ周辺の電磁場解析に用いられることが多い.

\section{4. 直接波のみのシミュレーション結果}

研究の第一段階として, 送信機（無線 LAN アクセスポイン ト）から伝搬した電波のうち，直接波のみの伝搬シミュレー ションを実装した。 このプログラムは 2 次元配列とした大域 地図を用いて送信機と各地点との見通しの有無を確認し見通 しがある場合について (3.1) 式を用いて電界強度を求めるも のである. 工学院大学新宿キャンパス 16 階の地図を用いたシ ミュレーション結果を図 4 に示す。この地図はロボットによ り取得された物ではなく CAD 図面から作成したものである. シミュレーション条件は $\mathrm{P}=200 \mathrm{~mW}, \lambda=0.125 \mathrm{~m}, \mathrm{Gt}=1 \mathrm{dBi}$, $\mathrm{Gr}=1 \mathrm{dBi}$ としている.

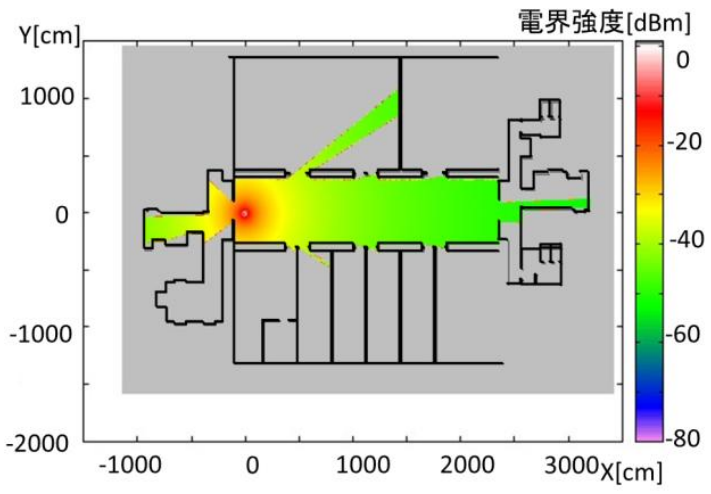

Fig.4 電波伝搬シミュレーション結果

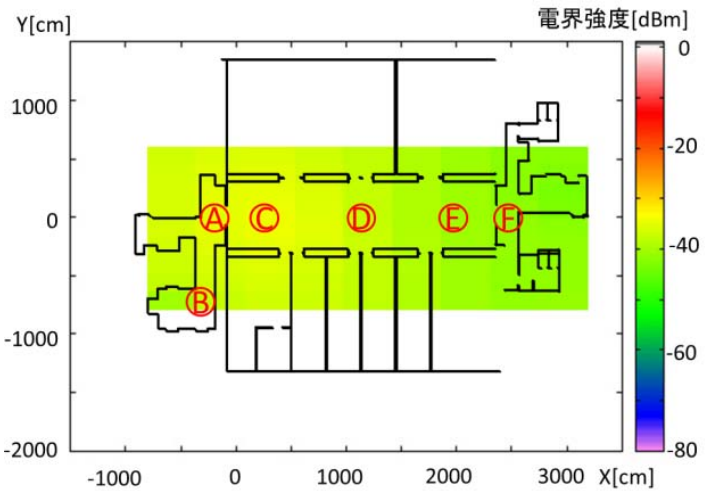

Fig.5 実測結果
Table1 実測值とシミュレーション值の比較

\begin{tabular}{|c|c|c|}
\hline 地点 & 推定值[dBm] & 実測值 $[\mathrm{dBm}]$ \\
\hline A & -21 & -32 \\
\hline B & 結果無し & -40 \\
\hline C & -21 & -30 \\
\hline D & -36 & -39 \\
\hline E & -41 & -43 \\
\hline F & -43 & -44 \\
\hline
\end{tabular}

またこの結果を検証するために同一条件で実機計測を行っ た結果を図 5 に，そのうち代表的な数力所についての結果の 比較を表 1 に示寸。シミュレーションによる推定值と実測值 を比較すると，第一に見通しがある部分については概ね良く 推定出来ているものの, 全体的にシミュレーションによる推 定值の方が実測值よりも高くなっており，その傾向は送信機 近傍において顕著になっている。この誤差の理由は送信機の 出力の誤差, 送信機内及び受信機内の減衰等が考えられる. ただし，本研究の目的は通信可能範囲の判別であるから，近 傍の誤差はそれほど問題とならないと考えている.

次に，見通しの効かない箇所においては，シミュレーショ ンでは電界強度が計算出来ていない点が大きく異なる。これ はシミュレーションが反射・回折・透過等の電波の性質を全 く考慮していないことが原因である。この点については通信 可能範囲の判別に大きく関わるため，上述の電波の諸性質を シミュレーション上に実装する必要である.

\section{5. 今後の予定}

今回は，まず簡単な直接波シミュレーションを行ったため, 見通しの効かないエリアで実測值と大きく異なる結果が得ら れたが，今後は他の諸性質を実装しより正確なレイトレース シミュレーションを行う。また，時間領域差分法でもシミュ レーション実装を行っているが，こちらは別の機会に報告す る。また，本論文では触れなかったが，物理層の電界強度を 推定しただけではアプリケーション層の通信状況を推定した ことにはならない。そのため，今後は電界強度の推定と併せ て，その際の通信スループットや通信エラー率を合わせて推 定する必要がある.

\section{文 献}

[1] 淺間,"原発事故対応のための遠隔操作機器の開発と運用",ロボッ 卜 (206),pp.33-38, 2012

[2] Keiji Nagatani, et. Al., "Redesign of rescue mobile robot Quince -Toward emergency response to the nuclear accident at Fukushima Daiichi Nuclear Power Station on March 2011-," Proc. of the 2011 IEEE SSRR, pp. 13-18, 2011.

[3] “福島第一原発の復旧支援を行う探査ロボットを東京電力に貸 与,”トピー工業株式会社ニュースリリース, http://www.topy.co.jp/release/archives/2012/03/06/entry502.ht $\mathrm{ml}$

[4] “東電, 原子炉建屋内で停止したクインスの扱いは未だに検討中”, 日刊工業新聞社 Robonable, http://www.robonable.jp/news/2011/10/quince-1028.html

[5] “トピー工業のロボットは回収困難、無線通信で救助できず、原 発事故調查”，日刊工業新聞社 Robonable, http://www.robonable.jp/news/2012/07/topv-0713.html

[6] 小暮他, “電磁界シミュレータで学ぶ高周波の世界”, CQ 出版社, ISBN978-4-7898-3022-5, 2010

[7] 宇野, “FDTD 法による電磁界およびアンテナ解析”, コロナ社, ISBN978-4-339-00689-6, 1998. 